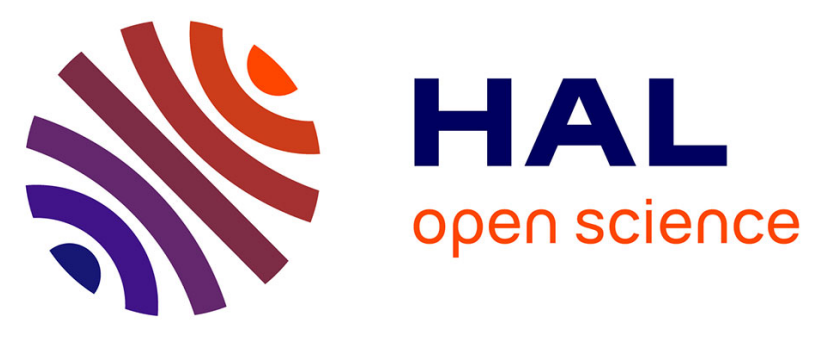

\title{
Prognostic value of soluble urokinase plasminogen activator receptor in patients presenting to the emergency department with chest pain suggestive of acute coronary syndrome
}

Camille Chenevier-Gobeaux, Hervé Lemarechal, Benoit Doumenc, Nicolas

Peschanski, Yann-Erick Claessens, Didier Borderie, Patrick Ray

\section{To cite this version:}

Camille Chenevier-Gobeaux, Hervé Lemarechal, Benoit Doumenc, Nicolas Peschanski, Yann-Erick Claessens, et al.. Prognostic value of soluble urokinase plasminogen activator receptor in patients presenting to the emergency department with chest pain suggestive of acute coronary syndrome. Clinical Biochemistry, 2021, 92, pp.19-24. 10.1016/j.clinbiochem.2021.02.009 . hal-03229056

\section{HAL Id: hal-03229056 https://hal.science/hal-03229056}

Submitted on 19 May 2021

HAL is a multi-disciplinary open access archive for the deposit and dissemination of scientific research documents, whether they are published or not. The documents may come from teaching and research institutions in France or abroad, or from public or private research centers.
L'archive ouverte pluridisciplinaire HAL, est destinée au dépôt et à la diffusion de documents scientifiques de niveau recherche, publiés ou non, émanant des établissements d'enseignement et de recherche français ou étrangers, des laboratoires publics ou privés. 


\section{CLB-D-20-00592 - revised manuscript}

Prognostic value of soluble urokinase plasminogen activator receptor in patients presenting to the Emergency Department with chest pain suggestive of acute coronary syndrome

Camille Chenevier-Gobeaux (1), Hervé Lemarechal (1), Benoit Doumenc (2), Nicolas Peschanski (3, 4), Yann-Erick Claessens (5), Didier Borderie (1, 6), Patrick Ray (7, 8).

\section{Authors' affiliations}

(1) Service de Diagnostic Biologique Automatisé, Hôpital Cochin, APHP.Centre Université de Paris, Assistance Publique des Hôpitaux de Paris (AP-HP), Paris, France. camille.gobeaux@aphp.fr

(2) Emergency Department, Hôpital Cochin, APHP. Centre - Université de Paris, Assistance Publique des Hôpitaux de Paris (AP-HP), Paris, France

(3) Emergency Department, Hôpital Pontchaillou, Centre Hospitalier Universitaire de Rennes, Rennes, France

(4) Faculté de médecine, Université Rennes-1, Rennes, France

(5) Emergency Department, Hôpital Princesse Grâce, Monaco

(6) Université de Paris, INSERM UMRs 1124, Environmental Toxicity, Therapeutic Targets, Cellular Signaling and Biomarkers, France

(7) Centre Régional Universitaire des Urgences, CHU Mitterrand, Dijon, France

(8) Université de Bourgogne, Dijon, France

\section{Corresponding author:}


Dr Camille Chenevier-Gobeaux, Service de Diagnostic Biologique Automatisé, Hôpital Cochin, Hôpitaux Universitaires Paris Centre (HUPC), Assistance Publique des Hôpitaux de Paris (AP-HP), Paris, France. camille.gobeaux@aphp.fr

Keywords: chest pain, emergency department, ED, soluble urokinase plasminogen activator receptor, suPAR, prognostic, outcome, 30-day event 


\section{Abstract}

Introduction: Soluble urokinase plasminogen activator receptor (suPAR) is a prognostic biomarker of cardiovascular disease. Objectives: We aimed to evaluate the early prognostic value of suPAR in patients presenting to the emergency department (ED) with chest pain suggestive of acute coronary syndrome (ACS). Patients and methods: in a post-hoc analysis from a multicenter study including patients with a chest pain $<6 \mathrm{~h}$, suPAR concentrations at ED admission were studied according to the outcome at 30-days. Results: 198 patients (median age 56 years) in whom $16 \%$ had an ACS, were included. Fifteen (7.3\%) patients presented a 30-day event. At ED admission, median (IQR) suPAR concentrations were higher in patients with a 30-day event in comparison to patients without event (4.54 (3.09-8.61) vs. 2.72 (2.10-3.43) ng/mL, $\mathrm{p}<0.001)$. The ROC curve AUC of suPAR for the prediction of a 30-days event was 0.775 [95\%CI: $0.710-0.831]$. The optimal threshold was $3.3 \mathrm{ng} / \mathrm{mL}$, with a sensitivity of 73 [45-92] \% and a specificity of $72[65-79] \%$. The association of a suPAR $<3.3$ ng/mL AND a NT-proBNP $<160$ ng/L AND a HEART score $<4$ had a negative predictive value of 99 [91- 100] \%. A suPAR value at admission above $3.3 \mathrm{ng} / \mathrm{mL}$ was independently and significantly associated with a 30-day event in chest pain emergency patients (OR 4.87 [1.35-17.51], $\mathrm{p}=0.015)$. Conclusion: suPAR is a promising biomarker for early prediction of events in chest pain emergency patients. 


\section{Introduction}

SuPAR is the soluble form of urokinase plasminogen activator receptor (uPAR), which is expressed mainly on immune cells, endothelial cells, and smooth muscle cells. During inflammation or immune activation, suPAR is released and therefore reflects the immune activation and inflammation [1]. Several studies have shown that the higher the suPAR concentration is, the higher the risk of disease progression and the worse the patient's prognosis, in critically ill patients [2, 3]. In emergency patients, suPAR is associated with age, comorbidities, length of stay, admission to intensive care unit (ICU), readmission within 30 and 90 days, and mortality [4]. In a large unselected population of 782 acute medical patients, suPAR remained predictor factor of readmission and mortality. A randomised controlled trial including more than 16.000 acute medical patients showed that patients who had suPAR level measured at admission, were significantly more often discharged within $24 \mathrm{~h}$ of admittance, in comparison to patients without suPAR measurement, without worsening prognostic [5].

Approximately 15 million patients per year presenting to US emergency departments (EDs) with symptoms suggestive of acute coronary syndrome (ACS). These last years, new assays of cardiac troponin (cTn) have been developed, and high sensitivity troponin (HS-cTn) has been associated with higher sensitivity than conventional cTn. The fourth universal definitions of myocardial infarction (MI) definitely recommended use of HsTn for evaluating chest pain suspected of ACS [6]. Previous studies reported that suPAR is elevated in patients with cardiovascular diseases, and is associated with ischemic heart disease [7] and AMI [8]. In patients with ST-segment elevation myocardial infarction (STEMI), the suPAR level was elevated the first 24 hours after admission, and suPAR values were significantly higher in nonsurvivors than in survivors [7].

We aimed to evaluate the early prognostic value of suPAR in patients presenting to the ED with chest pain suggestive of ACS, compared to that of usual cardiac biomarkers. 


\section{PATIENTS AND METHODS}

This is a post-hoc ancillary study of previous published works $[9,10]$. Briefly, we prospectively enrolled outpatients who presented to the ED with chest pain suggestive of ACS with the onset or peak occurring within the previous 6 hours, in three different ED. Patients with acute or chronic kidney failure were excluded. The study was performed according to the principles of the Declaration of Helsinki and approved by the local ethics committee, and Recommendations of the Standards for Reporting of Diagnostic Accuracy initiative were applied. At the time of the study, HEART score was not available but was calculated a posteriori for this study [11]. As recommended, we considered that a HEART score $<4$ was associated to a low risk of ACS [11].

The gold-standard diagnosis was adjudicated by two independent experts (emergency physician and cardiologist) who reviewed all available medical records (including patient history, physical findings, laboratory results and radiological testing, ECG, echocardiography, coronary angiography, summary chart at discharge) pertaining to the patient from the time of ED presentation to 30-day follow-up. Cases were reviewed and adjudicated in conjunction with a third expert if disagreement. Acute Myocardial Infarction (AMI) was diagnosed according to the universal definition that was in force at the time of inclusions $[9,10]$. Unstable angina (UA) diagnosis was adjudicated in patients with history or clinical symptoms consistent with acute coronary syndrome but without ST-T wave changes on the ECG and without change of cTn on serial testing. Other diagnostic categories besides STEMI, NSTEMI and UA were non-ACS (eg, stable angina, myocarditis, arrhythmias, heart failure, pulmonary embolism and chest pain of unknown origin). The follow-up of the patients was performed at day 30: if any event occured, the type and date of event was recorded (death, relapse of confirmed or suspected ACS, pericarditis, atrial fibrillation, acute heart failure).

The Flowchart of the studied population is on Figure 1. 


\section{Biochemical analysis}

Heparinized samples collected on admission. After routine cTn measurement, plasma samples were aliquoted and frozen $\left(-40^{\circ} \mathrm{C}\right)$ until HS-cTnT and suPAR measurements. Plasmatic HscTnT and NT-proBNP concentrations were measured using the electrochemiluminescence immunoassays (Elecsys2010® analyzer, RocheDiagnostics, Meylan, France). SuPAR plasmatic concentrations were measured using the suPARnostic ${ }^{\circledR}$ TurbiLatex kit (Virogates, Birkerød, Denmark) on a cobas c502 (Roche Diagnostics, Meylan, France). The suPARnostic ${ }^{\circledR}$ TurbiLatex test is a turbidimetric immunoassay that quantitatively determines suPAR in human plasma samples. The measuring range of the suPARnostic ${ }^{\circledR}$ TurbiLatex assay is from 1.5 to $16.0 \mathrm{ng} / \mathrm{mL}$. Our CVs during the study were $14.6 \%$ at $2.8 \mathrm{ng} / \mathrm{mL}, 3.6 \%$ at $5.8 \mathrm{ng} / \mathrm{mL}$ and $3.2 \%$ at $9.1 \mathrm{ng} / \mathrm{mL}$. These analytical performance levels were in accordance with data provided by the manufacturer. Manufacturer ensured stability of the suPAR on long-term plasma collection. Physicians were blinded to suPAR results when adjudication and biologists were blinded to outcome when performing the suPAR measurements.

\section{Statistical analysis}

Continuous variables are presented as median $\left(25^{\text {th }}-75^{\text {th }}\right.$ percentile $)$, categorical variables as numbers and percentages. Continuous variables were compared with the Mann-Whitney $U$ test and categorical variables using the Pearson chi-square test. Receiver-operator characteristic (ROC) curves were constructed to assess the sensitivity and specificity, positive (PPV) and negative predictive value (NPV) (all with their 95\% confidence interval $[95 \% \mathrm{CI}]$ ) throughout the concentrations of suPAR and others, to compare the accuracy of these biomarkers for riskstratification (30-days events). Comparison of areas under the ROC curves was performed. Biomarkers were considered alone or in combination for this analysis. We used logarithmic 
combination or best linear combination (BLC) method [12]. This latest method relies on the creation of a formula in which biomarkers of interest are moderated by their coefficient of covariance in the studied population. The obtained combination gives a score for each patient that can be studied as a biomarker by itself, and submitted to ROC analysis and logistic regression. As the ROC curve is recognized to be potentially insensitive, the Net Reclassification Index (NRI) method was used, as described [13]. For tests with binary outcomes, NRI is the same as the gain in certainty of the first test minus the gain in certainty of the second test, or alternatively stated, the differences of the sum of the sensitivity and specificity: $\mathrm{NRI}_{\text {second test vs first test }}=(\text { Sensitivity }+ \text { Specificity })_{\text {second test }}-($ Sensitivity + Specificity $)$ first test. NRI enables to quantify the benefit of the association in terms of number of patients correctly reclassified. When considered necessary, we created the reclassification table that offers a practical representation of both the relationship between false positive and false negative, and the magnitude of the gain of predictability in quantitative terms (number of patients).

A forward logistic regression was finally performed to assess variables associated with 30-days events. For this analysis, suPAR was evaluated as categorical variable based on the optimum cut-off point previously determined by ROC curve. Only variables with $p$ value $<0.10$ in the univariate analysis were included in the logistic regression. The discriminate power of the logistic regression was evaluated by the c-statistic (concordance index) and the goodness of fit of the model by the Hosmer-Lemeshow test. All hypothesis testing was 2-tailed, and a p value of $<0.05$ was considered significant. Statistical analysis was performed using MedCalc for ROC analysis (MedCalc Software, Mariakerke, Belgium). 


\section{Results}

\section{Baseline characteristics of the studied population}

Table 1 reports the baseline characteristics of the studied population with 31 (16\%) patients with ACS (STEMI: $\mathrm{n}=8$; NSTEMI: $\mathrm{n}=23$ ). Briefly, 15 patients $(7.6 \%)$ presented an event at day-30. Univariate analysis indicated that these patients were less frequently men, were older and had more frequently a HEART score $\geq 4$ and a final diagnosis of ACS. These patients also presented higher NT-proBNP and HS-cTnT concentrations at admission, in comparison to patients without event at day-30. Main causes of the 30-day outcome were relapse of ACS for 10 out of $15(66.7 \%)$ patients, death for $3(20.0 \%)$ patients, atrial fibrillation for 1 patient and pericarditis for 1 patient.

\section{Final diagnosis and SUPAR concentrations}

Median (IQR) suPAR concentrations at ED admission were significantly higher in patients with ACS in comparison to patients without $(3.93(3.00-5.07)$ vs. $2.86(2.20-3.66) \mathrm{ng} / \mathrm{mL}$, $\mathrm{p}<0.001)$

\section{Outcome and suPAR concentrations}

Median (IQR) suPAR concentrations at ED admission were significantly higher in the 168 patients that were hospitalized in comparison to patients that were not $(3.13(2.36-4.28)$ vs. $2.72(2.11-3.10) \mathrm{ng} / \mathrm{mL}, \mathrm{p}<0.001)$. Median suPAR concentrations at ED admission were also significantly higher in patients with a 30-day event in comparison to patients without (4.54 (3.09 - 8.61) vs. $2.72(2.10-3.43) \mathrm{ng} / \mathrm{mL}, \mathrm{p}<0.001)$. When classified according to the HEART score, median suPAR concentrations at ED admission were significantly higher in patients with HEART score $\geq 4(\mathrm{n}=108)$ in comparison to patients with HEART score $<4$ $(3.00(2.30-4.44)$ vs. $2.49(2.10-3.17) \mathrm{ng} / \mathrm{mL}, \mathrm{p}<0.001)$. 


\section{Prognostic performances of suPAR and other cardiac biomarkers}

The ROC curve AUC of suPAR was 0.775 [95\%CI: $0.710-0.831](\mathrm{p}<0.001)$ (Figure 2). The optimal threshold was $3.3 \mathrm{ng} / \mathrm{mL}$, and was associated to a sensitivity of $73 \%$ [45 - 92] and a specificity of $72 \%$ [65 - 79]. The ROC curve AUCs of the logarithmic combinations of biomarkers were not superior to that of suPAR. Alternatively, using the BLC method, we obtained the following combination: suPAR (in $\mathrm{ng} / \mathrm{mL}$ ) $+2408^{*} \mathrm{NT}$-proBNP (in $\mathrm{ng} / \mathrm{L}$ ). The ROC curve AUCs of this combination was not superior to that of suPAR (data not shown).

We further studied the prognosis performances of all biomarkers, alone or in combination (Table 2). Using the NRI method, suPAR and NT-proBNP alone classify better than other biomarkers patients according to 30-day event, as shown by the higher value of Sensitivity + Specificity.

When considering HEART score, we found that the association of a suPAR $<3.3 \mathrm{ng} / \mathrm{mL}$ AND a NT-proBNP $<160 \mathrm{ng} / \mathrm{L}$ AND a HEART score $<4$ had a sensitivity of 93\% [66 - 100] and a negative predictive value of $99 \%$ [91 - 100] to exclude a 30-day event. Sixty-nine patients (34.8\% of the studied population) could be rule out with this combination, and no one with ACS. However, this combination failed to better classify patients, as shown by the NRI (2) almlde the number of patients reclassified (Table 3).

\section{Logistic regression for 30-day event}

We finally performed a multiple logistic regression. For this analysis, we considered only variables with a $\mathrm{p}<0.10$ in univariate analysis (i.e., suPAR, NT-proBNP, HScTnT, dyslipidemia, diastolic BP, HEART score and sex, as indicated in Table 1). In chest pain emergency patients, suPAR and dyslipidemia were the only variables independently associated 
with a 30-day event patients. Indeed, a suPAR value at admission above $3.3 \mathrm{ng} / \mathrm{mL}$ was associated with a 30-day event patients (OR: 4.87 [95\%CI: $1.35-17.51], \mathrm{p}=0.015$, and 3.64 [95\%CI: 1.05-12.60], $\mathrm{p}=0.041$, respectively); the overall model was good (c-statistics $=0.818$ [95\%CI: 0.756-0.869]). Similar performances were obtained when including final diagnosis of ACS in the model (data not shown).

When considering the association of a suPAR $<3.3 \mathrm{ng} / \mathrm{mL}$ AND a NT-proBNP $<160 \mathrm{ng} / \mathrm{L}$ AND a HEART score $<4$, this combination was associated with an absence of 30-day event (OR 2.78 [95\%CI: $1.41-5.47], \mathrm{p}=0.003 ; \mathrm{c}-\mathrm{statistics}=0.845$ [95\%CI: 0.786-0.893]). 


\section{Discussion}

We aimed to evaluate the prognostic value of suPAR in patients presenting to the ED with chest pain suggestive of ACS. Our results indicated that (1) suPAR concentrations at admission were higher in chest pain patients with a 30-day event in comparison to patients without, and (2) a suPAR value at admission above $3.3 \mathrm{ng} / \mathrm{mL}$ was independently associated with a 30-day event. The association of a suPAR $<3.3 \mathrm{ng} / \mathrm{mL}$ and a NT-proBNP $<160 \mathrm{ng} / \mathrm{L}$ and a low HEART score had a high negative predictive value to exclude safely a 30-day event at ED admission.

Our results are in accordance with that of the literature. Our suPAR values are very similar to that obtained in 296 patients with STEMI treated with primary PCI. Indeed, the authors found that baseline suPAR values were significantly higher in non-survivors than in survivors (4.9 vs $3.9 \mathrm{ng} / \mathrm{mL}$ ) [7]. Furthermore, in patients with suspected ACS, suPAR demonstrated to be a strong predictor of mortality and of readmission due to heart failure (HF) and new MI [14]. Here again, suPAR values were higher in non-survivors than in survivors (6.0 vs $4.1 \mathrm{ng} / \mathrm{mL})$ in a similar way, but also in readmitted vs non-readmitted patients. Furthermore, suPAR AUC value that we observed in our study was in accordance to that obtained by Sörensen et al. [15]. We believe that our study is one of the first to report the association of suPAR to other cardiac biomarkers. Furthermore, we found that the association of a low value of suPAR AND a low value of NT-proBNP AND a low HEART score had an elevated negative predictive value. The present results are similar with a previous study indicated that suPAR was a tool for identification of patients at low risk of serious illness [16]. Our analysis indicated that a suPAR value at admission above $3.3 \mathrm{ng} / \mathrm{mL}$ is independently associated with a 30-day event in chest pain emergency patients (OR 3.55 [95\%CI: 1.15-10.93], $\mathrm{p}=0.027$ ). Most of the studies indicated a long-term value [7, 14]. Schultz et al [17] founded that, in 4420 patients, suPAR was significantly better in predicting mortality than triage, and that a cut-off of suPAR at $5.9 \mathrm{ng} / \mathrm{mL}$ potentially improves prediction of short-term mortality. More recently, same authors found that 
the readmission rate within 30 days was higher in the suPAR group [16], in patients with low risk of serious illness in ED. Furthermore, Hodges et al. sought to validate the (suPAR) for the prediction of death and MI, in a cohort of 1635 patients with suspected coronary artery disease [18]. They found that suPAR was independently associated with the combined endpoint of death/MI, cardiovascular death, and non-fatal MI. A plasma cutoff for suPAR $\geq 3.5 \mathrm{ng} / \mathrm{mL}$ was also significantly associated with death/MI. Our results may be compared to those obtained in other studies but with different time lapses of prognosis. Indeed, on one hand, the study of Sörensen et al. shows that suPAR does not help in acute triage [19], while on the other hand the study of Nikorowitsch et al. shows that suPAR has a strong and independent prognostic value in secondary prevention (3.5 years follow-up) [20]. Our study, in addition with the literature $[17,20]$, thus indicates that suPAR may be more suitable to predict early (30-days) as long-term (several years) prognosis. Thus, we believe that our study is one of the first to evaluate an early prognostic value in chest pain patients admitted to the ED. In addition, our study indicated an interesting association of HEART score (which is an easyto-use clinical score) and biomarkers at admission. Indeed, we found that the association of a low suPAR plus low NT-proBNP plus a low HEART score had a high negative predictive value to exclude a 30-day event. Furthermore, our study may be highlight the interest of having a biomarker of ED admission that may be useful to guide patients' follow-up after discharge. We are aware that our study presents some limits. First, this is a post-hoc analysis. Second, we were unable to test all included patients for suPAR analysis because of missing samples. Furthermore, we could not reach all patients for the follow-up. Thus, our findings were obtained on a limited sample size and should be confirmed in larger population. Finally, when the relapse of ACS was observed during the follow-up, some cases could not be confirmed and thus remained suspected. However, when performing the analysis without this suspected cases, our 
results were similar (data not shown). Thus, we believe that our results should be validated in a larger scale population with systematic and confirmed follow-up.

\section{Conclusion:}

We found that suPAR was an independent early predictor of events in chest pain emergency patients. The association of a low suPAR value and a low NT-proBNP value and a low HEART score at admission allowed to rule out safely a 30-day event in one third of our ED chest pain population. 


\section{References}

[1] Ploug M, J Eriksen, T Plesner, N E Hansen, K Danø. A soluble form of the glycolipidanchored receptor for urokinase-type plasminogen activator is secreted from peripheral blood leukocytes from patients with paroxysmal nocturnal hemoglobinuria. Eur J Biochem 1992;208:397-404. https://doi.org/10.1111/j.1432-1033.1992.tb17200.x

[2] Donadello K, Scolletta S, Taccone FS, Covajes C, Santonocito C, Orbegozo Cortes D, Grazulyte D, Gottin L, Vincent JL. Soluble urokinase-type plasminogen activator receptor as a prognostic biomarker in critically ill patients. J Crit Care 2014;29:144-9. https://doi.org/10.1016/j.jcrc.2013.08.005

[3] Rasmussen LJH, Ladelund S, Haupt TH, Ellekilde GE, Eugen-Olsen J, Andersen O. Combining National Early Warning Score With Soluble Urokinase Plasminogen Activator Receptor (suPAR) Improves Risk Prediction in Acute Medical Patients: A Registry-Based Cohort Study. Crit Care Med 2018; 46:1961-1968. https://doi.org/10.1097/ccm.0000000000003441

[4] Rasmussen LJH, Ladelund S, Haupt TH, Ellekilde G, Hjelm Poulsen J, Iversen K, EugenOlsen J, Andersen O. Soluble urokinase plasminogen activator receptor (suPAR) in acute care: a strong marker of disease presence and severity, readmission and mortality. A retrospective cohort study. Emerg, Med J 2016;33:769-75. https://doi.org/10.1136/emermed-2015-205444

[5] Schultz M, Rasmussen LJH, Høi-Hansen T, Kjøller E, Jensen BN, Lind MN, Ravn L, Kallemose T, Lange T, Køber L, Rasmussen LS, Eugen-Olsen J, Iversen KK. Early Discharge from the Emergency Department Based on Soluble Urokinase Plasminogen Activator Receptor (suPAR) Levels: A TRIAGE III Substudy. Dis Markers. 2019: 3403549. https://doi.org/10.1155/2019/3403549 
[6] Thygesen K, Alpert JS, Jaffe AS, Chaitman BR, Bax JJ, Morrow DA, White HD, ESC Scientific Document Group. Fourth universal definition of myocardial infarction (2018). J Am Coll Cardiol. 2018; 72: 2231-2264. https://doi.org/10.1016/j.jacc.2018.08.1038

[7] Lyngbæk S, Marott JL, Møller DV, Christiansen M, Iversen KK, Clemmensen PM, EugenOlsen J, Jeppesen JL, Hansen PR. Usefulness of soluble urokinase plasminogen activator receptor to predict repeat myocardial infarction and mortality in patients with ST-segment elevation myocardial infarction undergoing primary percutaneous intervention. Am $J$ Cardiol 2012; 110: 1756-63. https://doi.org/10.1016/j.amjcard.2012.08.008

[8] Schernthaner C, Lichtenauer M, Wernly B, Paar V, Pistulli R, Rohm I, Jung C, Figulla HR, Yilmaz A, Cadamuro J, Haschke-Becher E, Pernow J, Schulze PC, Hoppe UC, Kretzschmar D. Multibiomarker analysis in patients with acute myocardial infarction. Eur J Clin Invest. 2017; 47: 638-48. https://doi.org/10.1111/eci.12785

[9] Freund Y, Chenevier-Gobeaux C, Bonnet P, Claessens YE, Allo JC, Doumenc B, Leumani F, Cosson C, Riou B, Ray P. High-sensitivity versus conventional troponin in the emergency department for the diagnosis of acute myocardial infarction. Crit Care 2011; 15:R147. https://doi.org/10.1186/cc10270

[10] Chenevier-Gobeaux C, Freund Y, Claessens YE, Guérin S, Bonnet P, Doumenc B, Leumani F, Cosson C, Allo JC, Riou B, Ray P. Copeptin for rapid rule out of acute myocardial infarction in emergency department. Int J Cardiol 2013; 166:198-204. https:// doi.org/10.1016/j.ijcard.2011.10.098

[11] Long B, Oliver J, Streitz M, Koyfamn A. An end-user's guide to the HEART Score and pathway. Am J Emerg Med 2017; 35:1350-5. https://doi.org/10.1016/j.ajem.2017.03.047.

[12] Su JQ et Liu JS. Linear combinations of multiple diagnostic markers. J Am Stat Assoc. $1993 ; 88: 1350-5$. 
[13] Ray P, Le Manach Y, Riou B, Houle TT. Statistical evaluation of a biomarker. Anesthesiology. 2010; 112:1023-40. https://doi.org/10.1097/aln.0b013e3181d47604

[14] Lyngbæk S, Andersson C, Marott JL, Møller DV, Christiansen M, Iversen KK, Clemmensen P, Eugen-Olsen J, Hansen PR, Jeppesen JL. Soluble urokinase plasminogen activator receptor for risk prediction in patients admitted with acute chest pain. Clin Chem. 2013; 59:1621-9. https://doi.org/10.1373/clinchem.2013.203778

[15] Sörensen NA, Nikorowitsch J, Neumann JT, Rübsamen N, Goßling A, Hartikainen TS, Blankenberg S, Westermann D, Zeller T, Karakas M. Predictive value of soluble urokinasetype plasminogen activator receptor for mortality in patients with suspected myocardial infarction. Clin Res Cardiol . 2019; 108:1386-1393. https://doi.org/10.1007/s00392-019$\underline{01475-1}$

[16] Schultz M, Rasmussen LJH, Kallemose T, Kjøller E, Lind MN, Ravn L, Lange T, Køber L, Rasmussen LS, Eugen-Olsen J, Iversen K. Availability of suPAR in emergency departments may improve risk stratification: a secondary analysis of the TRIAGE III trial. Scand J Trauma Resusc Emerg Med. 2019; 27:43. https://doi.org/10.1186/s13049-019$\underline{0621-7}$

[17] Schultz M, Rasmussen LJH, Høi-Hansen T, Kjøller E, Jensen BN, Lind MN, Ravn L, Kallemose T, Lange T, Køber L, Rasmussen LS, Eugen-Olsen J, Iversen KK. Early Discharge from the Emergency Department Based on Soluble Urokinase Plasminogen Activator Receptor (suPAR) Levels: A TRIAGE III Substudy Dis Markers. 2019; 2019:3403549. https://doi.org/10.1155/2019/3403549

[18] Hodges G, Lyngbæk S, Selmer C, Ahlehoff O, Theilade S, Sehestedt TB, Abildgaard U, Eugen-Olsen J, Galløe AM, Hansen PR, Jeppesen JL, Bang CN. SuPAR is associated with death and adverse cardiovascular outcomes in patients with suspected coronary artery 
$\begin{array}{lllll}\text { disease } & \text { Scand } & \text { Cardiovasc } & \text { J. } & 2020 ;\end{array}$

https://doi.org/10.1080/14017431.2020.1762917

[19] Sörensen NA, Dönmez G, Neumann JT, Nikorowitsch J, Rübsamen N, Blankenberg S, Westermann D, Zeller T, Karakas M. Diagnostic Value of Soluble Urokinase-Type Plasminogen Activator Receptor in Addition to High-Sensitivity Troponin I in Early Diagnosis of Acute Myocardial Infarction. Biomolecules. 2019 Mar 18;9(3):108. doi: 10.3390/biom9030108.

[20] Nikorowitsch J, Borchardt T, Appelbaum S, Ojeda F, Lackner KJ, Schnabel RB, Blankenberg S, Zeller T, Karakas M. Cardio-Renal Biomarker Soluble Urokinase-Type Plasminogen Activator Receptor Is Associated With Cardiovascular Death and Myocardial Infarction in Patients With Coronary Artery Disease Independent of Troponin, C-Reactive Protein, and Renal Function. J Am Heart Assoc. 2020 Apr 21;9(8):e015452. 


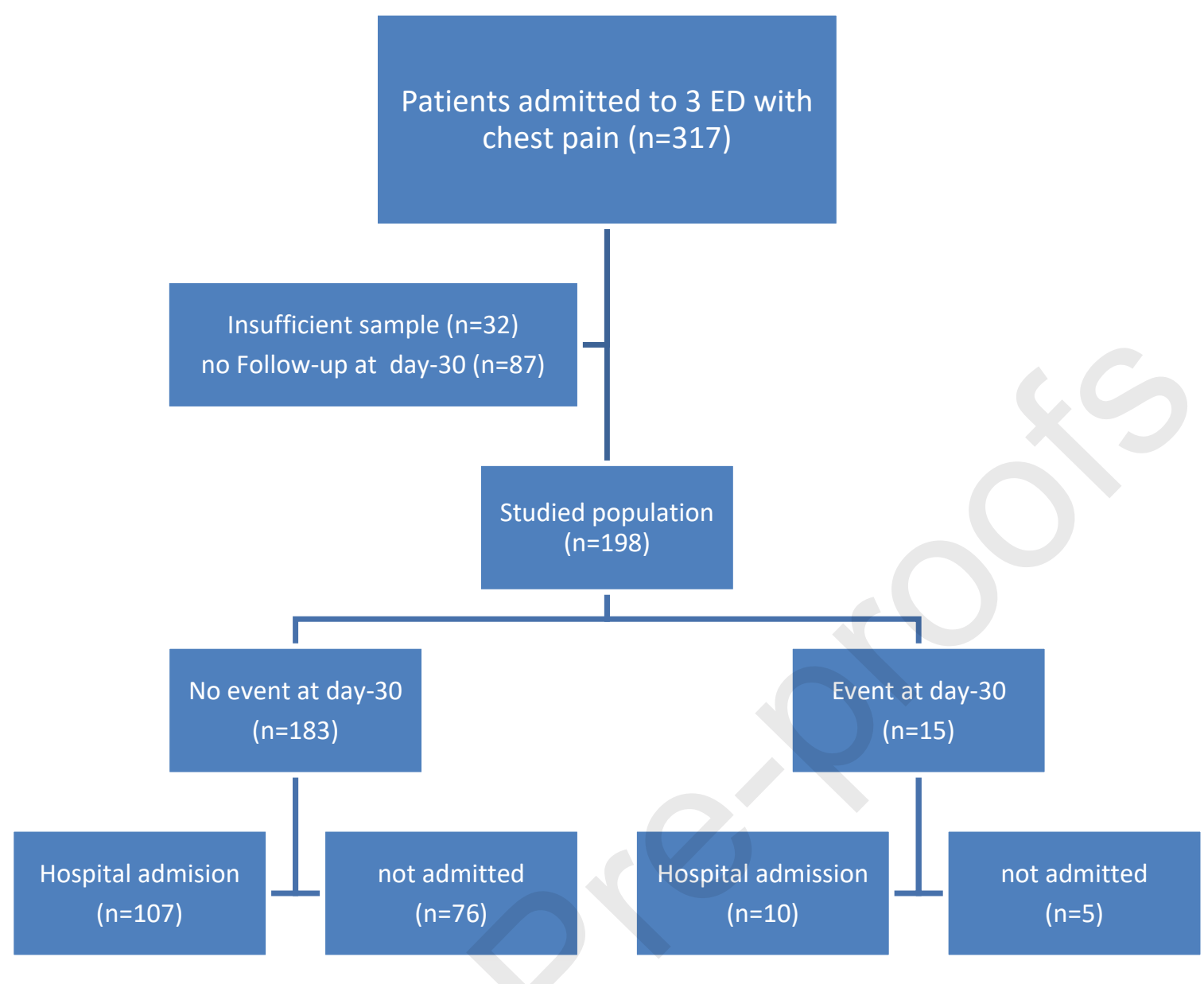

Figure 1. Flowchart of the studied population 

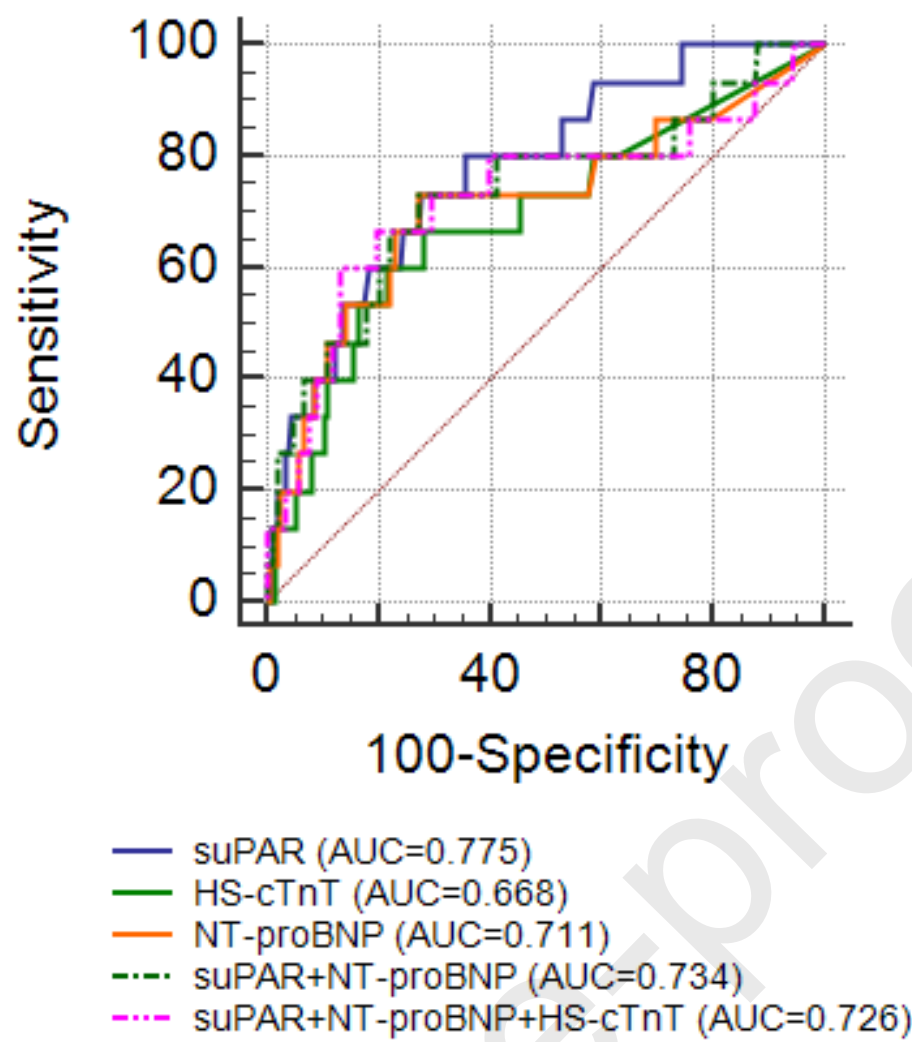

Table 1. Baseline characteristics of studied population according to the 30-day event.

\begin{tabular}{|l|l|l|l|l|}
\hline & All patients & \multicolumn{2}{|c|}{ Univariate analysis } \\
\hline & & No 30-day event & $30-$ day event & $p$ \\
\hline N & 198 & 183 & 15 & \\
\hline Men - n (\%) & $129(65 \%)$ & $123(67.2 \%)$ & $6(40.0 \%)$ & 0.034 \\
\hline Age -years & $56(44-69)$ & $55(44-68)$ & $78(46-85)$ & 0.025 \\
\hline Hypertension - n (\%) & $72(36.4 \%)$ & $64(34.9 \%)$ & $8(53.3 \%)$ & 0.156 \\
\hline Familial history of CAD -n(\%) & $71(35.9 \%)$ & $66(36.0 \%)$ & $5(33.3 \%)$ & 0.821 \\
\hline Dyslipidemia - n (\%) & $76(38.4 \%)$ & $67(36.6 \%)$ & $9(60.0 \%)$ & 0.076 \\
\hline Diabetes - n (\%) & $29(14.6 \%)$ & $25(13.6 \%)$ & $4(26.6 \%)$ & 0.172 \\
\hline Personal history of HF - n (\%) & $14(7.0 \%)$ & $14(7.8 \%)$ & $0(0 \%)$ & 0.278 \\
\hline Smoke - n (\%) & $78(3.4 \%)$ & $74(40.4 \%)$ & $4(26.7 \%)$ & 0.295 \\
\hline Systolic BP (mm Hg) & $141(123-157)$ & $141(124-157)$ & $146(115-177)$ & 0.896 \\
\hline Diastolic BP(mm Hg) & $80(70-91)$ & $80(70-91)$ & $70(67-80)$ & 0.058 \\
\hline Heart rate & $78(67-91)$ & $79(68-91)$ & $74(58-88)$ & 0.286 \\
\hline Saturation (\%) & $98(96-99)$ & $98(96-99)$ & $97(96-98)$ & 0.339 \\
\hline
\end{tabular}


Journal Pre-proofs

\begin{tabular}{|c|c|c|c|c|}
\hline Admission - n (\%) & $117(59.0 \%)$ & $107(58.4 \%)$ & $10(66.7 \%)$ & 0.536 \\
\hline HEART Score $\geq 4$ & $108(54.5 \%)$ & $95(51.9 \%)$ & $13(86.7 \%)$ & 0.010 \\
\hline \multicolumn{5}{|l|}{ Treatments received } \\
\hline Aspirin $-\mathrm{n}(\%)$ & $75(37.9 \%)$ & $68(37.2 \%)$ & $7(46.7 \%)$ & 0.487 \\
\hline Clopidogrel - n (\%) & $34(17.2 \%)$ & $29(15.8 \%)$ & $5(33.3 \%)$ & 0.090 \\
\hline LMW heparin - n $(\%)$ & $42(21.2 \%)$ & $38(20.7 \%)$ & $4(26.7 \%)$ & 0.608 \\
\hline Nitrate $-\mathrm{n}(\%)$ Beta- & $27(13.6 \%)$ & $24(13.1 \%)$ & $3(20.0 \%)$ & 0.480 \\
\hline blockers - n (\%) & $21(10.6 \%)$ & $19(10.4 \%)$ & $2(13.3 \%)$ & 0.740 \\
\hline Coronarography & $50(25.3 \%)$ & $47(25.7 \%)$ & $3(20.0 \%)$ & 0.611 \\
\hline \multicolumn{5}{|l|}{ Final diagnosis } \\
\hline $\mathrm{ACS}-\mathrm{n}(\%)$ & $31(15.7 \%)$ & $25(13.7 \%)$ & $6(40.0 \%)$ & 0.009 \\
\hline non $\mathrm{ACS}-\mathrm{n}(\%)$ & $167(84.3 \%)$ & $158(86.3 \%)$ & $9(60.0 \%)$ & \\
\hline \multicolumn{5}{|c|}{ Plasma biomarkers at admission } \\
\hline HS-cTnT(ng/L) & $4.9(3.0-13.8)$ & $4.5(3-11.8) 86$ & $4.2(18.7-65.4)$ & 0.013 \\
\hline HS-cTnT $\geq 5$ ng/L $-n(\%)$ & $97(49.0 \%) 49$ & $(46.2 \%) 40$ & $11(73.3 \%)$ & 0.050 \\
\hline HS-cTnT $\geq 14$ ng/L $-n(\%)$ & $(24.7 \%) 56$. & $(21.9 \%) 53$ & $9(60.0 \%)$ & 0.001 \\
\hline NT-proBNP (ng/L) & $(17.0-253) 61$ & $(14.2-199) 50$ & $556(71.2-3338)$ & 0.006 \\
\hline NT-proBNP $\geq 160 \mathrm{ng} / \mathrm{L}-\mathrm{n}(\%)$ & $(30.8 \%$ & $(27.3 \%) 85(70-$ & $11(73.3 \%)$ & $<0.001$ \\
\hline Creatinin $(\mu \mathrm{mol} / \mathrm{L})$ & $86(71-99)$ & 99) 2.72 & $95(75-113)$ & 0.197 \\
\hline suPAR (ng/mL) & $2.80(2.17-3.64)$ & $(2.10-3.43) 51$ & $4.54(3.09-8.61)$ & $<0.001$ \\
\hline $\mathrm{suPAR} \geq 3.3 \mathrm{ng} / \mathrm{mL}-\mathrm{n}(\%)$ & $62(31.3 \%)$ & $(27.9 \%)$ & $11(73.3 \%)$ & $<0.001$ \\
\hline \multicolumn{5}{|l|}{ 30-day event } \\
\hline Relapse of ACS - n (\%) & $10(5.1 \%)$ & $0(0 \%)$ & $10(66.7 \%)$ & / \\
\hline Death $-\mathrm{n}(\%)$ & $3(1.5 \%)$ & $0(0 \%)$ & $3(20.0 \%)$ & \\
\hline Pericarditis $-\mathrm{n}(\%)$ & $1(0.5 \%)$ & $0(0 \%)$ & $1(6.7 \%)$ & \\
\hline atrial fibrillation $-\mathrm{n}(\%)$ & $1(0.5 \%)$ & $0(0 \%)$ & $1(6.7 \%)$ & \\
\hline
\end{tabular}

Number (\%) or median (IQR)

ACS, Acute coronary syndrome; CAD, coronary artery disease; LMW, low molecular weight 
Table 2. Prognosis performances of suPAR for 30-days event

\begin{tabular}{|c|c|c|c|c|c|c|}
\hline & $\begin{array}{l}\text { Se \% } \\
{[95 \% \mathrm{CI}]}\end{array}$ & Spe \% $[95 \% C I]$ & $\begin{array}{l}\mathrm{VPN} \% \\
{[95 \% \mathrm{CI}]}\end{array}$ & $\begin{array}{l}\text { VPP \% } \\
{[95 \% C I]}\end{array}$ & $\begin{array}{l}\text { Se }+ \\
\text { Spe }\end{array}$ & NRI \\
\hline $\operatorname{suPAR} \geq 3.3 \mathrm{ng} / \mathrm{mL}\left({ }^{*}\right)$ & $73[45-91]$ & $72[65-78]$ & 97 [92-99] & $18[10-30]$ & 145 & / \\
\hline NT-proBNP $\geq 160 \mathrm{ng} / \mathrm{L}\left({ }^{*}\right)$ & $73[45-91]$ & $73[66-79]$ & 97 [92-99] & $18[10-30]$ & 146 & $+1 \%$ \\
\hline HS-cTnT $\geq 5$ ng/L (**) & $73[45-91]$ & $53[46-60]^{p<0.001 \text { vs suPAR }}$ & 96 [90-99] & $11[6-19]$ & 126 & $-19 \% \%^{p<0.001 \text { vs suPAR }}$ \\
\hline HS-cTnT $\geq 14 \mathrm{ng} / \mathrm{L}(* * *)$ & $60[33-83]$ & $78[71-84]$ & 96 [91-98] & $18[9-32]$ & 138 & $-7 \%$ \\
\hline suPAR $\geq 3.3 \mathrm{ng} / \mathrm{mL}$ and/or HS-cTnT $\geq \mathbf{5} \mathrm{ng} / \mathrm{L} 80$ & {$[51-95] 41[3$} & $-49]^{\mathrm{p}<0.001 \text { vs suPAR } 96[88-\mathrm{C}}$ & $10[6-17] 121$ & & & $-24 \% \mathrm{p}^{\mathrm{p}<0.001 \text { vs suPAR }}$ \\
\hline suPAR $\geq 3.3 \mathrm{ng} / \mathrm{mL}$ and/or HS-cTnT $\geq 14 \mathrm{ng} / \mathrm{L}$ & $3[45-91] 59[$ & $2-66]^{p=0.009}$ vs suPAR $96[90$ & 9] 13 [7-22] 13 & & & $-14 \%{ }^{p}=0.010$ vs suPAR \\
\hline $\begin{array}{l}\text { suPAR } \geq 3.3 \mathrm{ng} / \mathrm{mL} \text { and/or NT-proBNP } \\
\geq 160 \text { and/or HS-cTnT } \geq 5 \mathrm{ng} / \mathrm{L}\end{array}$ & $80[51-95]$ & $39[32-47]^{\mathrm{p}<0.001 \text { vs suPAR }}$ & 96 [88-99] & $10[6-17]$ & 119 & $-26 \%{ }^{p<0.001 \text { vs suPAR }}$ \\
\hline $\begin{array}{l}\text { suPAR } \geq 3.3 \mathrm{ng} / \mathrm{mL} \text { and/or NT-proBNP } \\
\geq 160 \text { and/or HS-cTnT } \geq 14 \mathrm{ng} / \mathrm{L}\end{array}$ & $80[51-95]$ & $52[45-59]^{\mathrm{p}<0.001 \text { vs suPAR }}$ & 97 [88-98] & $12[7-20]$ & 131 & $-14 \%{ }^{p<0.001 \text { vs suPAR }}$ \\
\hline $\begin{array}{l}\text { suPAR } \geq 3.3 \mathrm{ng} / \mathrm{mL} \text { and/or NT-proBNP } \\
\geq 160 \mathrm{ng} / \mathrm{L} \text { and/or HEART } \geq 4\end{array}$ & $93[66-100]$ & $37[30-44]^{p<0.001 \text { vs suPAR }}$ & 99 [91-100] & $11[6-18]$ & 130 & $-15 \% \mathrm{p}<0.001$ vs suPAR \\
\hline
\end{tabular}

(*) optimal threshold given by ROC analysis; (**) $5 \mathrm{ng} / \mathrm{L}$ is the Limit of Detection of the method; (***) $14 \mathrm{ng} / \mathrm{L}$ is the URL of the method 
Table 3. Net reclassification improvement for the combination of suPAR, NT-proBNP and HEART score in comparison to suPAR alone, for the prediction of 30-days outcome

\begin{tabular}{|c|c|c|c|c|c|}
\hline & suPAR $<3.3 \mathrm{ng} / \mathrm{mL}$ & $\begin{array}{llr}\text { suPAR } & <3.3 & \mathrm{ng} / \mathrm{mL} \\
\text { AND } & \text { NT-proBNP } \\
<160 & \mathrm{ng} / \mathrm{L} \quad \text { AND } \\
\text { HEART } & \text { score }<4\end{array}$ & $\operatorname{suPAR} \geq 3.3 \mathrm{ng} / \mathrm{mL}$ & $\begin{array}{l}\text { suPAR } \geq 3.3 \mathrm{ng} / \mathrm{mL} \\
\text { and/or } \quad \text { NT-proBNP } \\
\geq 160 \quad \mathrm{ng} / \mathrm{L} \text { and/or } \\
\text { HEART } \text { score } \geq 4\end{array}$ & Reclassification \\
\hline No 30-days event & 132 & 68 & 51 & 115 & -64 \\
\hline 30-days event & 4 & 1 & 11 & 14 & +3 \\
\hline \multicolumn{5}{|l|}{ Total } & -61 \\
\hline
\end{tabular}


